\title{
In vitro Studies on Calcium Oxalate Induced Apoptosis Attenuated by Didymocarpus pedicellata
}

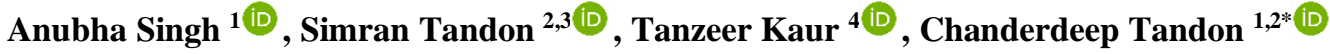 \\ 1 Amity Institute of Biotechnology (AIB), Amity University, Noida, Uttar Pradesh, India; anubhasinghest88@gmail.com \\ (A.S.); ctandon1@amity.edu (C.T.); \\ 2 Amity University Punjab, Mohali, India ctandon1@pb.amity.edu (C.T.); standon@pb.amity.edu (S.T.); \\ 3 Amity Institute of Molecular Medicine and Stem Cell Research (AIMMSCR) standon1@amity.edu (S.T.); \\ 4 Department of Biophysics, Panjab University, Chandigarh, India; tanzeer.kaur.biophysics@ gmail.com (T.K.); \\ * Correspondence: ctandon1@pb.amity.edu (C.T.)
}

Scopus Author ID:8302449900

Received: 30.09.2021; Revised: 1.11.2021; Accepted: 4.11.2021; Published: 24.11.2021

\begin{abstract}
The present study focuses on exploring the antilithiatic potential of Didymocarpus pedicellata, which is valuable in managing renal disorders. Urolithiasis is an idiopathic disorder with a high recurrence and an incidence rate and is of major concern worldwide due to partial and unsatisfactory relief. Calcium oxalate crystals in contact with renal epithelial cells (HK2), causing reactive oxygen species overproduction, oxidative stress, apoptosis resulting in crystal adhesion and internalization. Crystals were modulated by cotreatment with ethanolic extract of $D$. pedicellata. Cell toxicity assay was assessed using flow cytometry. Cell-crystal interaction, adhesion, and internalization were visualized through Scanning electron microscopy (SEM) analysis and hematoxylin-eosin staining. The lithogenic induction caused impairment of renal function due to oxidative stress, measured by ROS levels. Cell death assays were detected by dual staining methods. Fluorimeter evaluation pointed to active caspase 3 mediated cell death (apoptotic) in oxalate injured cells was attenuated by Didymocarpus pedicellata extract. Alterations in cell adhesion were observed by immunocytochemistry. The current study revealed that the Didymocarpus pedicellata was endowed with antiurolithiatic activity as it displayed increased viability, reduced oxidative stress due to lowered production of intracellular reactive oxygen species (ROS), and decreased apoptosis when oxalate injured HK2 cells were cotreated with the extract.
\end{abstract}

Keywords: apoptosis; oxidative stress; urolithiasis; didymocarpus pedicellata extract; crystal-cell adhesion; hyperoxaluria.

\section{Introduction}

Urolithiasis is a multifaceted, systemic disease usually caused as a result of acquired or congenital metabolic disturbances. Crystal formation accounts for the vast majority of cases with calculous disease [1,2]. The accumulation of calcium oxalate crystals in renal parenchyma contributes to the pathological features of nephrocalcinosis, interstitial fibrosis, chronic kidney disease, acute kidney disease, and eventually culminating in renal failure $[3,4]$. The formation of renal calculi is a multifactorial process that starts with urinary supersaturation, crystal nucleation, growth, and aggregation, leading to crystal adhesion in renal cells [5]. Oxalate nephropathies can induce oxidative stress and produce reactive oxygen species (ROS), thereby causing inflammation, oxidative damage, and apoptosis in renal epithelial cells and inducing the development of kidney stones [6,7]. Crystal-cell interaction leads to cellular injury and modifications in cell composition, structure, or physiology, leading to cell death [8]. Cell death 
caused by calcium oxalate $(\mathrm{CaOx})$ crystals is extensively studied, but the mode of apoptosis and necrosis remains unclear to date. Renal cells exposed to calcium oxalate crystals lead to significant apoptotic alternations, including DNA fragmentation, condensation of nuclear chromatin, and translocation of phosphatidylserine (PS) of the plasma membrane to the cell surface and dislocation of membrane proteins [9-11]. Many researchers have demonstrated that cells exposed to varying concentrations of $\mathrm{CaOx}$ crystals result in plasma membrane disintegration and inflammation due to necrosis [12-14]. The elevated level of free radicals leads to a decrease in antioxidant status, causing cellular injury, facilitating crystal adhesion and retention, and finally, cell death $[15,16]$.

The use of herbal medicines is very popular in traditional systems of medicine such as ayruvedic, unani, chinese, and homeopathy. Medicinal plants used in such systems are rich natural compounds that exhibit a wide range of ethnopharmacological activities. Such medicines can be attributed to their affordability, diminished side effects, relative safety, and easier access, making them a better treatment option for the underprivileged population $[17,18]$. Numerous investigations on medicinal formulations used in folklore are being used for their antilithiatic activity, which has aroused immense interest within the research community. Didymocarpus pedicellata R.Br. (Gesneriaceae), a well recognized medicinal plant commonly known as Pathar phori, stone flower, or shilapushpa is widely distributed in subtropical regions of the western Himalayas. There is extensive use of this herb in renal ailments, majorly against bladder stones and kidney diseases [19,20]. D.pedicellata is a major component of cystone, an ayurvedic formulation [21] used to treat renal afflictions such as neuro-ureterolithiasis [22], urolithiasis [23], burning micturition [24], and other disorders.

Secondary metabolites identified in $D$. pedicellata include didymocarpene, didymocarpol, didymocarpenol [25], and Didymocarpin [26]. Recent investigation shows that renal tubular injury due to calcium oxalate exposure increases the expression of stone modulatory protein osteopontin (OPN), which is also implicated in aggravation of inflammatory response [27,28]. Oxalate exposure induces oxidative stress, apoptosis, and adhesion of $\mathrm{CaOx}$ crystals in renal epithelial cells, thereby enhancing the formation of kidney stones $[29,30]$. This present study focuses on the protective effect of $D$. pedicellata on oxidative stress and apoptosis of HK2 cells injured due to oxalate exposure.

\section{Materials and Methods}

\subsection{Materials.}

All chemicals used were of analytical grade. Dulbecco's Modified Eagle's Medium (DMEM) (Sigma-Aldrich), penicillin G (100 units $/ \mathrm{mL})$-streptomycin $(10,000 \mu \mathrm{g} / \mathrm{mL})$ (Gibco), fetal bovine serum (FBS) (Gibco), 0.25\% Trypsin (Gibco), Cystone (Himalaya Herbal Healthcare), 0.4\% trypan blue solution (Himedia), Phosphate Buffer Saline (PBS) (Himedia), Sodium Oxalate (Himedia), Acridine orange (AO; MP Biomedicals), Ethidium Bromide (EtBr; MP Biomedicals), DCFH-DA (Thermo Scientific), Propidium Iodide (PI) (Himedia), Paraformaldehyde (PFA; Sigma-Aldrich), Glutraldehyde (Sigma- Aldrich), Phosphate Buffer Saline (PBS; Himedia), Triton X (Sigma-Aldrich), Bovine serum albumin (BSA; SigmaAldrich), 4',6-diamidino-2-phenylindole (DAPI; Sigma-Aldrich, India), DNase (Qiagen), Osteopontin (OPN- \#sc21742, Santa Cruz). 
The apparatus included Accuri C6 flow cytometer (BD Sciences), flow cytometry (FACS Aria III, BD Biosciences), fluorescence microscope (Leica DMIRE2, Germany), and optical microscope (Nikon Ti eclipse).

\subsection{Plant material.}

Didymocarpus pedicellata was purchased, identified, and authenticated from a registered company with certification number QC-S-17. The vendor powdered the plant through an electric grinder, and the powdered plant rhizome was stored in an airtight container, sealed properly, and kept at ambient temperature. For the preparation of the stock solution, 10 $\mathrm{g}$ dried and powdered plant rhizome was soaked in $40 \mathrm{~mL}$ ethanol and kept in an incubator for $24 \mathrm{~h}$ at $37^{\circ} \mathrm{C}$. The filtrate was collected in a flask by passing it through a Whatman grade 1 filter paper and evaporated to dryness using a Rotary Evaporator under reduced pressure and stored at $4^{\circ} \mathrm{C}$ until further use [31]. The ayurvedic drug Cystone, a commercial product of Himalaya Herbal Healthcare (Batch no-19800469), was purchased through local vendors (Noida, India) and was taken as the positive control.

\subsection{Cell culture.}

To evaluate the antilithiatic efficacy of ethanolic extract of D.pedicellata on renal epithelial cells, experiments were carried out on Human kidney proximal tubular epithelial cell line (HK2), purchased from ATCC, USA(CRL-2190). Cells were maintained in Dulbecco's Modified Eagle's Medium (DMEM) supplemented with $1 \%$ penicillin G (100 units $/ \mathrm{mL}$ )streptomycin $(10,000 \mu \mathrm{g} / \mathrm{mL})$ and $10 \%$ fetal bovine serum (FBS). Cells were cultured in $100 \mathrm{~mm}$ tissue-culture treated dishes and kept at $37{ }^{\circ} \mathrm{C}$ and $5 \% \mathrm{CO} 2$ in humidified chambers (Eppendorf, New Brunswick- Galaxy 170S).

\subsubsection{Sample preparation for cell line studies.}

The stock solution was prepared from ethanolic extract of D.pedicellata $(1 \mathrm{mg} / \mathrm{mL})$, dissolved in DMEM serum-free media, and filtered through a $0.22 \mu \mathrm{m}$ syringe filter. DMEM serum-free media was used to prepare the ethanolic extract's serial dilutions $(10-1000 \mu \mathrm{g} / \mathrm{mL})$. The concentration of DMSO in the extracts used for the various assays did not exceed $0.4 \%$ $\mathrm{v} / \mathrm{v}$. Cystone was taken as the positive control.

\subsubsection{Oxalate crystal preparation.}

Sodium oxalate $(10 \mathrm{mM})$ stock solution was prepared for cell line studies, filtered through a microsyringe filter of $0.22 \mu \mathrm{m}$, and sterilized under UV light in a laminar airflow for $3 \mathrm{hrs}$. Sodium oxalate was diluted to $2 \mathrm{mM}$ in serum-free DMEM medium, and HK2 cells were exposed to $2 \mathrm{mM}$ sodium oxalate with the various concentrations of ethanolic extract of D.pedicellata or Cystone.

\subsubsection{Determination of cell viability.}

Cell viability was assessed by trypan blue assay. Cells were seeded in 12 well plates at a density of $5 \times 104$ cells per well till they were approximately $70 \%$ confluent. The cells were then injured with $2 \mathrm{mM}$ sodium oxalate and treated with ethanolic extract of varying concentrations $(10 \mu \mathrm{g} / \mathrm{mL}-1000 \mu \mathrm{g} / \mathrm{mL})$ for $24 \mathrm{hrs}$. The trypsinized cells were taken in a 
microcentrifuge tube, and 1:1 mixture of the suspended cells was prepared by adding $10 \mu \mathrm{l}$ of the $0.4 \%$ trypan blue dye solution. The cell suspension and trypan blue dye mixture was loaded on the hemocytometer and observed under the optical microscope. The healthy live cells efficiently eliminate the dye from their cytoplasm, while the injured cells lose this potential and appear blue Cell viability was calculated by counting living cells and dead cells using the following formula, \%Cell Viability= (number of living cells/ total cell count $)^{*} 100$

\subsubsection{Detection of cell death.}

To evaluate cell toxicity, propidium iodide (PI) staining was performed using flow cytometry, Accuri C6 flow cytometer (BD Sciences). For PI cell toxicity assay, cells were seeded in a 6-well plate at a density of $2 \times 10^{5}$ cells $/ \mathrm{mL}$ and subsequently treated with $2 \mathrm{mM}$ sodium oxalate in the presence of the ethanolic extract of D.pedicellata for $24 \mathrm{~h}$. After the treatment, the supernatant was collected in a centrifuge tube and pooled with the trypsinized cells. The cell pellet was washed thrice with $1 \mathrm{X}$ PBS, and $5 \mu \mathrm{L}$ PI $(5 \mu \mathrm{g} / \mathrm{mL})$ staining solution was added. The cells were then incubated in the dark for 10-15 min. Subsequently, the cells were washed twice with PBS and analyzed for the presence of cell death.

\subsubsection{Observation of crystal adhesion by SEM.}

Scanning electron microscopy was performed to visualize the impact of cell-crystal interaction, adhesion, and morphology modulation due to oxalate injury. $4 \%$ paraformaldehyde and $1 \%$ glutaraldehyde were used to fix HK2 cells when treated with oxalate and extracted for 30 mins at room temperature. The coverslips were washed twice with $1 \mathrm{X}$ PBS, dehydrated, and air-dried overnight. The dried coverslips were then mounted on aluminum stubs and coated with chromium. Crystal internalization and morphology were then examined under a scanning electron microscope (ZEISS EVO HD, Germany).

\subsubsection{Crystal-cell interaction.}

The H\&E staining method was used to reduce the cytoplasmic light transmittance and visualize cell-crystal interaction through an optical microscope. Briefly, HK2 cells were seeded on sterile coverslips placed in a 6-well plate as $10^{5}$ cells/coverslips. Plates were kept overnight and then treated as previously described. For the control group, the culture media of cells was substituted with serum-free DMEM containing, $\mathrm{CaOx}(2 \mathrm{mM})$, and the test group was cotreated with $D$. pedicellata extract $(100 \mu \mathrm{g} / \mathrm{mL})$ for $24 \mathrm{hrs}$. Cystone $(200 \mu \mathrm{g} / \mathrm{mL})$ was taken as a positive control. The samples were fixed with 4\% PFA for 15-20 mins at room temperature, washed with PBS, and stained with Mayer's hematoxylin solution for 5 mins. Samples were then washed with distilled water and 1X PBS. Slides were dipped in $70 \%$ and $90 \%$ ethanol sequentially for $1 \mathrm{~min}$ each, then counterstained with alcoholic eosin for 5 mins. Slides were dehydrated with $100 \%$ ethanol for $1 \mathrm{~min}$ and observed under Nikon Eclipse Ti eclipse microscope under 20x objective.

\subsubsection{ROS levels detection.}

A non-fluorescent probe 2,7-dichlorodihydrofluorescein diacetate (DCFH-DA) was used to detect the levels of oxidant species. ROS generation due to oxalate injury and its cotreatment with ethanolic extract of D.pedicellata was monitored using DCFHDA. After the action time was reached, cells were rinsed with PBS three times, incubated with $10 \mu \mathrm{mol} / \mathrm{L}$ 
DCFH-DA at $37{ }^{\circ} \mathrm{C}$ for $20 \mathrm{~min}$, and then washed twice with PBS to remove the extracellular DCFHDA. The samples were then analyzed by FACS (Aria III, BD Biosciences).

\subsubsection{Detection of apoptosis and necrosis.}

Acridine orange (AO) and ethidium bromide (EB) staining, a biochemical method was used to investigate apoptotic morphology and characteristic features of cell death (apoptosis and necrosis), which included changes such as the disintegration of cell membrane and disorganization of the nucleus. HK 2 cells were seeded with a density of $2 \times 10^{5}$ cells/well till the cells were semi-confluent. The cells were injured with oxalate and treated with ethanolic extract of D.pedicellata for $24 \mathrm{hrs} .100 \mu \mathrm{g} / \mathrm{mL}$ concentration of the extract was chosen as it showed maximum cytoprotective potential as corroborated by trypan blue assay. Following the treatment period, cells were washed twice with 1x PBS and the PBS removed; for each test sample, $10 \mu \mathrm{L}$ solution containing an equivalent quantity of $\mathrm{EB}(50 \mu \mathrm{g} / \mathrm{mL})$ and $\mathrm{AO}(50 \mu \mathrm{g} / \mathrm{mL})$ of fluorescent dye at room temperature for $5 \mathrm{~min}$ in the dark and photographed within $15 \mathrm{~min}$, under a fluorescence microscope (Nikon eclipse, Ti) at a magnification of $20 \times$.

\subsubsection{Detection of apoptosis through active caspase- 3 .}

Caspase 3 is one of the major markers of cells undergoing apoptosis and was detected through the Caspase 3 kit (BD Biosciences). A synthetic fluorescent probe, Ac-DEVD-AMC is used to quantify caspase 3 activity in apoptotic cells. Activation of caspase-3 leads to cleavage of Ac-DEVD-AMC, fluorescent AMC is released, which is then quantified. Cells were seeded in $60 \mathrm{~mm}$ dishes at a density of $2 \times 10^{5}$ cells and treated as previously described. After the treatment period, cells were washed with PBS, resuspended in a cold Cell Lysis Buffer, and incubated for 30 mins on ice. $5 \mu \mathrm{L}$ reconstituted Ac-DEVD-AMC was added to $200 \mu \mathrm{L}$ HEPES buffer containing $50 \mu \mathrm{L}$ of cell lysate for each reaction and incubated for $1 \mathrm{hr}$ at $37^{\circ} \mathrm{C}$. The amount of AMC liberated from Ac-DEVD-AMC was measured using a fluorimeter at an excitation wavelength of $380 \mathrm{~nm}$ and an emission wavelength range of 420$460 \mathrm{~nm}$, as per the manufacturer's instructions.

\subsubsection{Detection of the cell surface adhesion molecule osteopontin (OPN).}

The cell concentration was $1.0 \times 105$ cells $/ \mathrm{mL}, 2 \mathrm{~mL} /$ well was seeded in a confocal dish and incubated at $37^{\circ} \mathrm{C}$ for $24 \mathrm{~h}$. The experiment grouping is the same as 2.2.7. After reaching the incubation time, aspirate the culture solution, wash twice with PBS, and fix with paraformaldehyde for 15 minutes, block with goat serum for 20 minutes, and drop the primary anti-osteopontin $(1: 100)$ and incubate overnight at $4^{\circ} \mathrm{C}$. After the incubation time is reached, wash with PBS 3 times, add FITC secondary antibody dropwise and incubate at $37{ }^{\circ} \mathrm{C}$ for 0.5 $\mathrm{h}$ in the dark, and finally, stain the nucleus with DAPI for $10 \mathrm{~min}$. The OPN expression was qualitatively observed under a laser confocal microscope, and the OPN fluorescence was semiquantitatively analyzed by ImageJ software.

\subsubsection{Statistical analysis.}

All data were calculated and shown as mean \pm SD (Standard deviations). The statistical analysis was done by using one-way ANOVA $(\mathrm{p}<0.05)$ and two-way analysis of variance (ANOVA) to estimate the differences between values and tested using Graph Pad Prism software version 6.2. 


\section{Results and Discussion}

At present, the factors involved in urolithiasis and its underlying mechanism remain elusive. During the formation of kidney stones, tubular epithelial cells are exposed to these crystals. Kidney stone disease has a high recurrence rate of over $50 \%$ in a 10 -year time period. Treatment options such as shock wave lithotripsy lead to tissue damage, which further promotes increased crystal deposition, increasing the chances of recurrent stone formation [32]. Owing to the multifactorial nature of kidney stone disease, efficient therapy to manage and prevent lithiasis is still limited despite a lot of research in this field. Apoptosis is a form of autonomous and programmed cell death, which is important for maintaining homeostasis and plays a complex role in numerous biological processes of multicellular organisms [33-35]. Recent studies have shown that the formation of renal calculi is intrinsically linked to the injury and apoptosis of renal cells [36,37]. Due to the invasive nature of $\mathrm{CaOx}$ crystals, there is a dire need to find medicinal plants with potent antioxidants that can prevent ROS generation. Previous studies indicated that oxidative stress contributes to the pathogenesis of various diseases $[38,39]$. The current study was performed to investigate the antilithiatic potential of ethanolic extract of $D$. pedicellata. HK 2 cells were injured with $\mathrm{CaOx}$ crystals which caused toxicity and decreased viability.

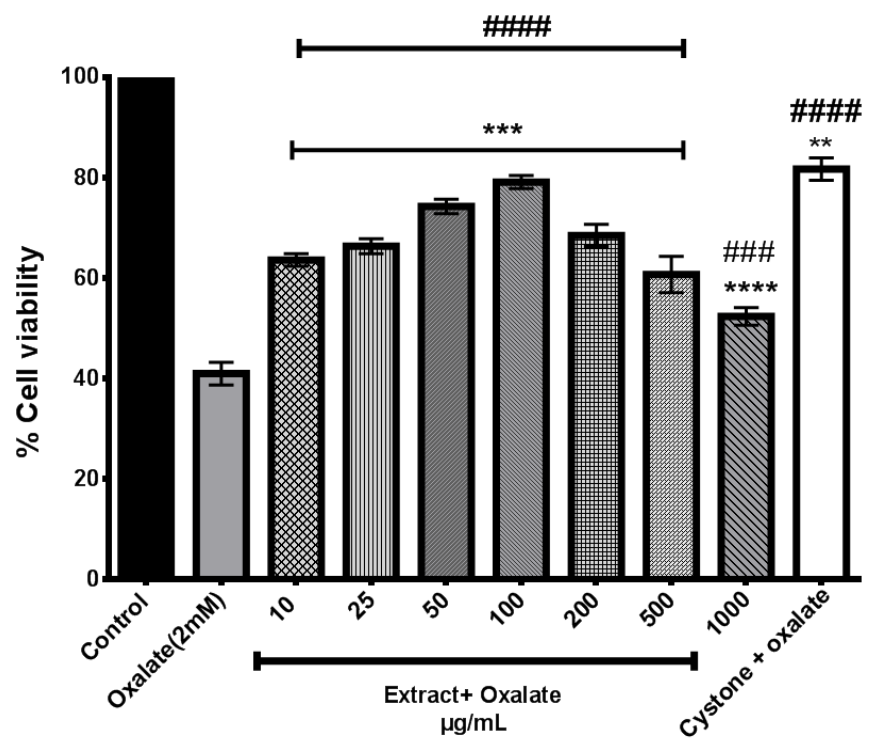

Figure 1. D.pedicellata exerts cytoprotective effect against oxalate injured human renal cells (HK2 cells). The graph shows the average cell viability observed following treatment for 24 hrs. Data are mean \pm SD of three

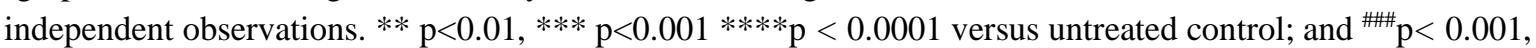
\#\#\# $\mathrm{p}<0.0001$ versus oxalate treated cells.

Cell viability was evaluated by trypan blue exclusion assay; it evaluates the number of live cells after exposure to $\mathrm{CaOx}$ crystals and their concomitant treatment with D.pedicellata extract. Cell toxicity induced due to $\mathrm{CaOx}$ crystals was evaluated on HK2 cells, which drastically reduced the cell viability from $100 \%$ in untreated cells to $40.96 \pm 2.25 \%$ within 24 h. However, cotreatment with test concentrations of D.pedicellata increased cell viability in a dose-dependent manner, with maximum viability observed in the cells treated with 100 $\mu \mathrm{g} / \mathrm{mL}(79.10 \pm 1.31 \%)$ as observed in Figure 1, which is comparable to the positive control, cystone at $100 \mu \mathrm{g} / \mathrm{mL}(81.7 \pm 2.20 \%)$. As the maximum protection of the ethanolic extract was seen with the $100 \mu \mathrm{g} / \mathrm{mL}$, this concentration was used to study the potential antilithiatic effect of D.pedicellata against oxalate injury in the subsequent experiments. The cotreatment of HK2 
cells injured due to oxalate exposure with $D$. pedicellata showed maximum cell viability at 100 $\mu \mathrm{g} / \mathrm{mL}$, as shown by trypan blue assay.

Cell toxicity and membrane disintegration were determined by Propidium Iodide staining. This fluorescent dye penetrates disintegrated cell membranes of the late apoptotic and necrotic cells. PI staining results were evaluated, and maximum viable cells in the unstained and control group (Figure 2) mainly consist of healthy cells with fewer PI-positive cells. Cell death was highest in cells treated with CCCP (87.3\%) and oxalate injured cells (42.3\%). Cells co-treated with ethanolic extract of D.pedicellata $(100 \mu \mathrm{g} / \mathrm{mL})$ showed a reduction in cell death to $26.2 \%$.

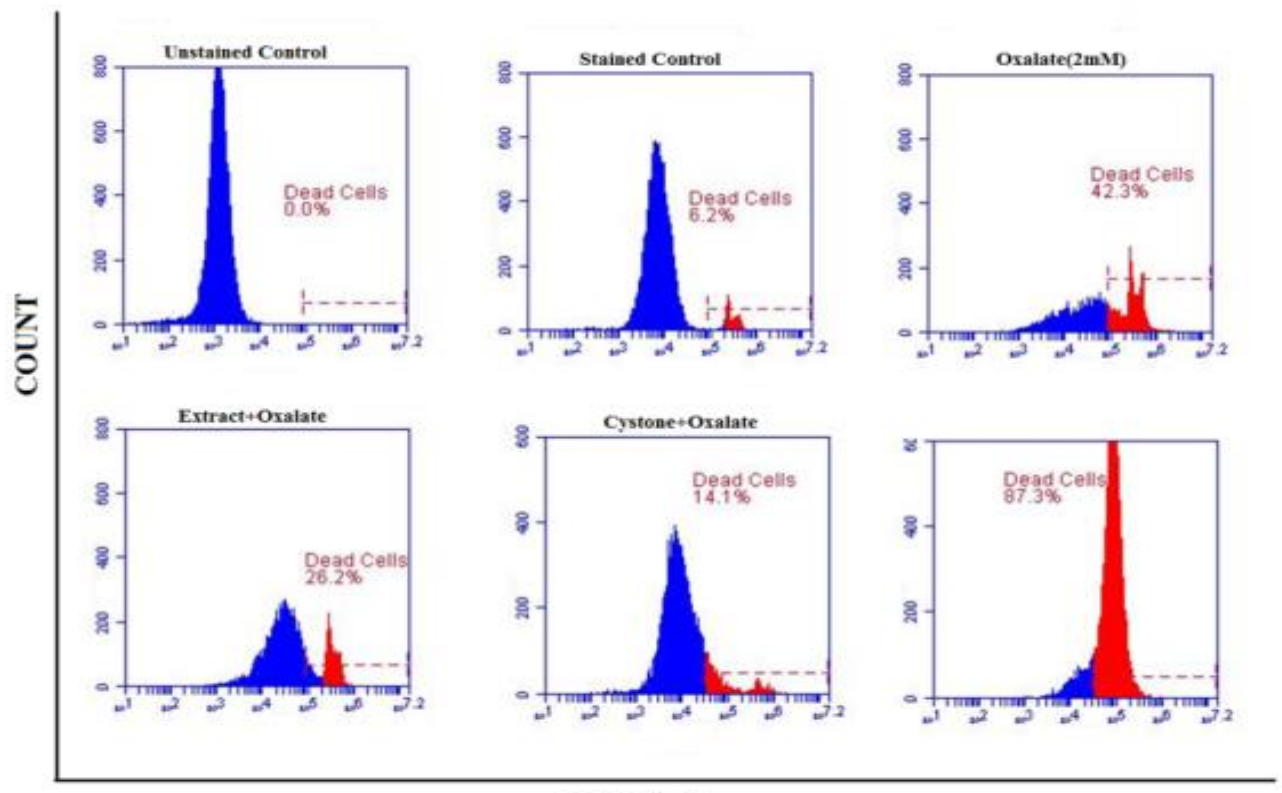

PI(FL2-A)

Figure 2. Cytotoxic effect of calcium oxalate crystals on HK2 renal epithelial cells and protective effect of D.pedicellata extract $(100 \mu \mathrm{g} / \mathrm{mL})$. Representative image of PI staining cytotoxicity assay on oxalate induced cell death in HK2 cells visualized by flow cytometry. CCCP $(10 \mu \mathrm{M})$ was taken as a positive control for cell death.

SEM and H\&E analysis showed that the oxalate crystals completely disintegrated and altered to unstable COD crystals with cotreatment of D. pedicellata extract. COM crystals cause maximum injury to renal epithelial cells as they are thermodynamically more stable than COD crystals $[40,41]$. Cell-crystal contact was observed to ascertain the extent of oxalate damage caused to the HK2 cells and was visualized under a scanning electron microscope (SEM). Calcium oxalate exists in 2 distinct crystalline forms; calcium oxalate dihydrate (COD) and calcium oxalate monohydrate (COM). COM crystals have a hexagonal shape with sharp edges, whereas; COD crystals are bipyramidal in structure, making them less harmful towards cells [42]. SEM images of oxalate injured cells revealed the presence of a large number of COM crystals of varying sizes adhered to the surface. However, upon cotreatment, the antilithiatic potential of ethanolic extract of D.pedicellata $(100 \mu \mathrm{g} / \mathrm{mL})$ was observed in renal epithelial cells (Figure 3), as the deleterious effect of COM crystals was visibly curbed and there was a significant change from COM to COD crystals which are less damaging. The dissolution of crystals was observed as the numbers of COM crystals were broken. The crystal structure is converted from a thermostable hexagonal, elongated form to a soluble COD form. Similar results were seen in the cells treated with cystone. 

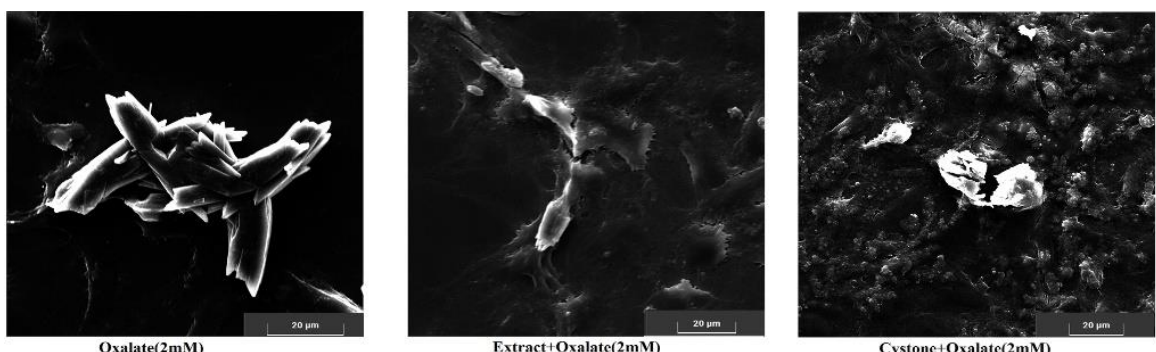

Figure 3. COM crystals adhered to HK2 renal epithelial cells were analyzed by SEM. The treatment of cells shows modulation of crystal morphology. COM treated group, COM+ D.pedicellata extract, and COM + Cystone.

An alteration in cell morphology directly affects the degree of cell damage. The control group presented uniformly stained cytoplasm. In COM-treated cells, we observed the morphology changes in cells injured with COM crystals through the $\mathrm{H}$ and E staining assay. As shown in Figure 4, cells were damaged with oxalate, which led to a dramatic alteration in the morphology of renal tubular cells from a cuboidal epithelial phenotype to spindle-like fibroblast-type accompanied by chromatin condensation apoptotic body formation. The cytoprotective role of ethanolic extract of $D$. pedicellata helps in the breakdown of COM crystals adhered HK2 cells were examined under a phase microscope. Cystone showed restoration of the morphology, which was evident in the $\mathrm{H} \& \mathrm{E}$ stained cells.

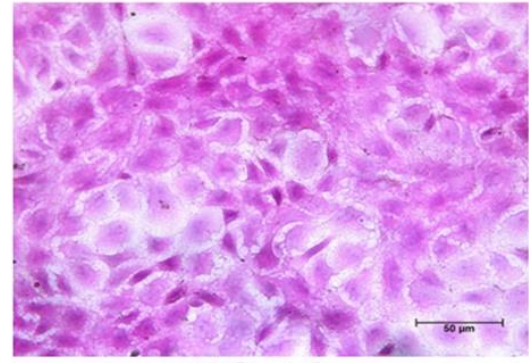

(a) Control

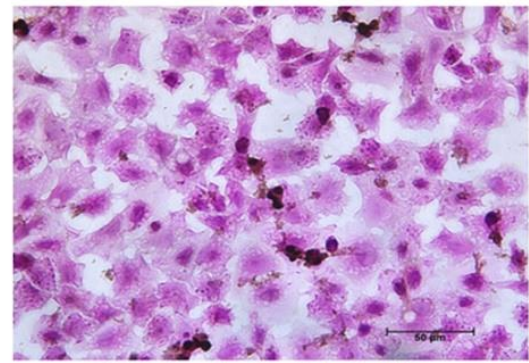

(c) Extract+ Oxalate(2mM)

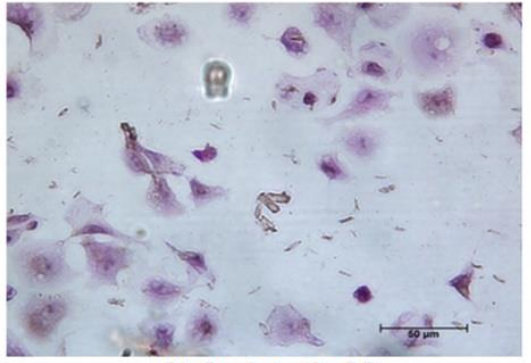

(b) Oxalate (2mM)

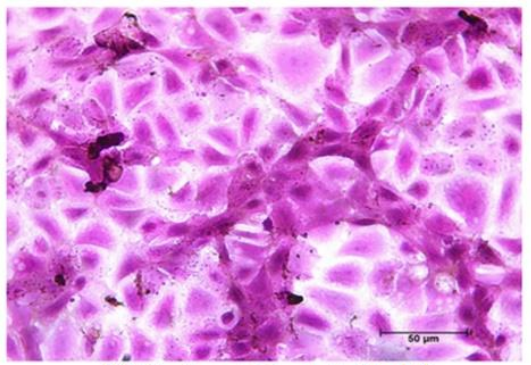

(d) Cystone+ Oxalate $(2 \mathrm{mM})$

Figure 4. Morphology alterations were observed by HE staining of HK-2 cells when exposed to COM crystals under a phase microscope. Cotreatment with D.pedicellata extract $(100 \mu \mathrm{g} / \mathrm{mL})$ significantly modulated the cell structure to its original form. Scale bars: $50 \mu \mathrm{m}$.

In the present study, we observed Hyperoxaluria induced cell injury-causing extensive reactive oxygen species (ROS) production, which leads to apoptosis. Changes in intracellular ROS production in cells using a flow cytometry-based assay as seen in Figure 5. DCFDA is a cell-permeant fluorogenic dye that measures intracellular ROS. DCFDA is cleaved by cellular esterases and oxidized due to peroxidases and $\mathrm{H}_{2} \mathrm{O}_{2}$ to generate the 2,7-dichlorofluorescein (DCF), which is fluorescent and measured. Compared to the normal group, HK-2 cells in the oxalate injured group have the strongest fluorescence intensity, indicating that the ROS level was the highest $(67.9 \%)$ cells compared to the untreated controls (39\%). When the oxalate 
injured cells were cotreated with the $D$. pedicellata extract $(100 \mu \mathrm{g} / \mathrm{mL})$, a dramatic reduction in the fluorescence intensity of ROS was observed (46.5\%).

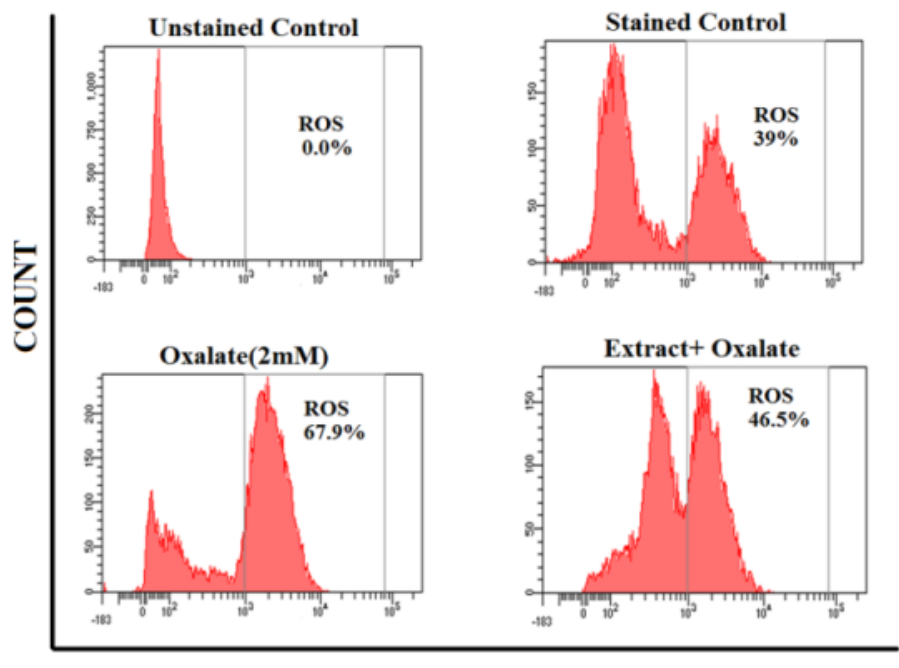

FITC-DCFDA

Figure 5. Intracellular ROS generation was determined by DCFDA by oxalate injured cells and their cotreatment with $D$. pedicellata extract measured by flow cytometer.

Crystal-cell interaction and adhesion is a preliminary and vital step, followed by internalization of crystals generating an inflammatory reaction, ultimately causing injury, toxicity leading to cell death $[43,44]$. Cell death mode was confirmed by dual staining fluorescent microscopy. This investigation revealed HK2 cells injured by oxalate have distinctly disorganized and disintegrated nuclei, showing signs of both apoptosis and necrosis.
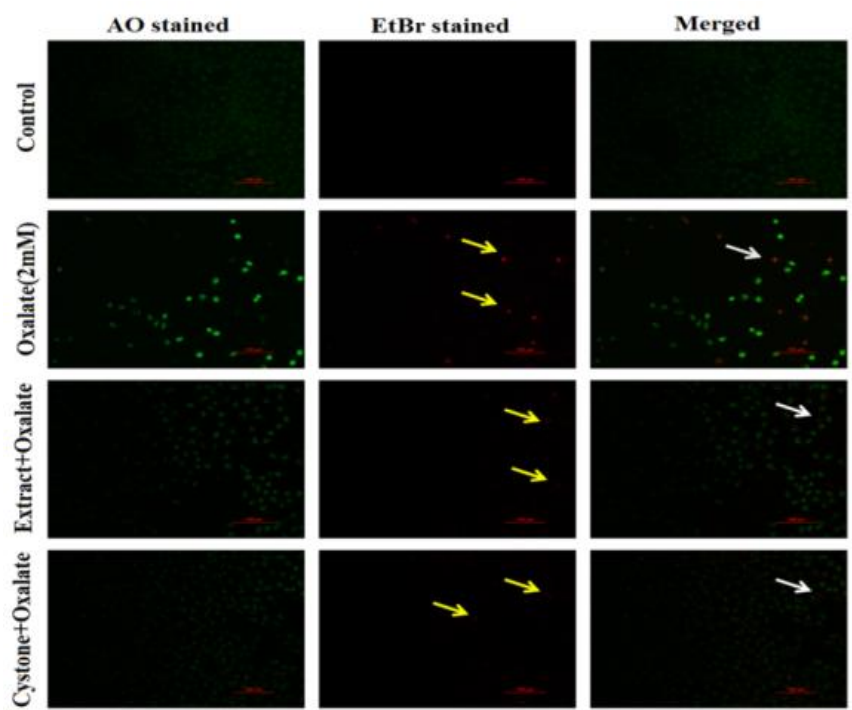

Figure 6. Control group: AO dye stains the cells uniformly. Oxalate group(early apoptotic cells): cells showed yellow-green fluorescence due to AO staining; in the late apoptotic cells, the nucleus showed orange fluorescence, by EB staining and the necrotic cells showed orange-red fluorescence due to disintegration. Extract +Oxalate showed a decrease in late apoptotic and necrotic cells. Yellow arrows depict early apoptotic cells (bright green-stained cells), white arrows indicate late apoptotic and necrotic cells (orange-red stained).

Dual staining was done to examine the mechanism of cell death under a fluorescent microscope. No significant apoptosis was detected in the control group as the cytoplasm retains the AO (Acridine Orange) dye uniformly and no intake of Ethidium bromide(EtBr) dye. In the oxalate injured group, early-stage apoptosis and necrosis with granular yellow-green AO nuclear staining and late-stage apoptosis marked by localized Ethidium bromide(EtBr) staining 
was observed. A significant increase of necrotic cells was shown as uneven orange-red fluorescence. The cells appeared to be in the process of disintegrating. Oxalate injured group when cotreated with $D$. pedicellata extract $(100 \mu \mathrm{g} / \mathrm{mL})$ and Cystone there is a visible decrease in fluorescence due to their antilithiatic potential as seen in Figure 6.

In our study, a fluorimeter was used to analyze apoptosis by Caspase 3 is an essential enzyme for the final execution of the apoptosis pathway [45-47]. Cells that are undergoing apoptosis exhibit the presence of active Caspase-3, while normal healthy cells contain an inactive isoform of the executioner Caspase-3 enzyme. Ac-DEVD-AMC is a synthetic fluorescent probe that is used to estimate caspase 3 activity in apoptotic cells. Our results depicted that the control group has negligible levels of active caspase 3 . CCCP $(10 \mu \mathrm{M})$, which is a positive control for apoptosis, showed a significant level of the enzyme (36088 \pm 5845$)$. HK2 cells injured due to oxalate crystal exposure also significantly increased active caspase-3 enzyme (24156 \pm 5531.7$)$, which revealed that the cells underwent death through apoptosis. Cytoprotective role of ethanolic extract of D. pedicellata $(100 \mu \mathrm{g} / \mathrm{mL})$ against oxalate-induced toxicity significantly reduced the expression of caspase-3(14698 \pm 187$)$, as seen in Figure 7. Results of the caspase 3 assay can be correlated with the apoptosis assays done in this study.

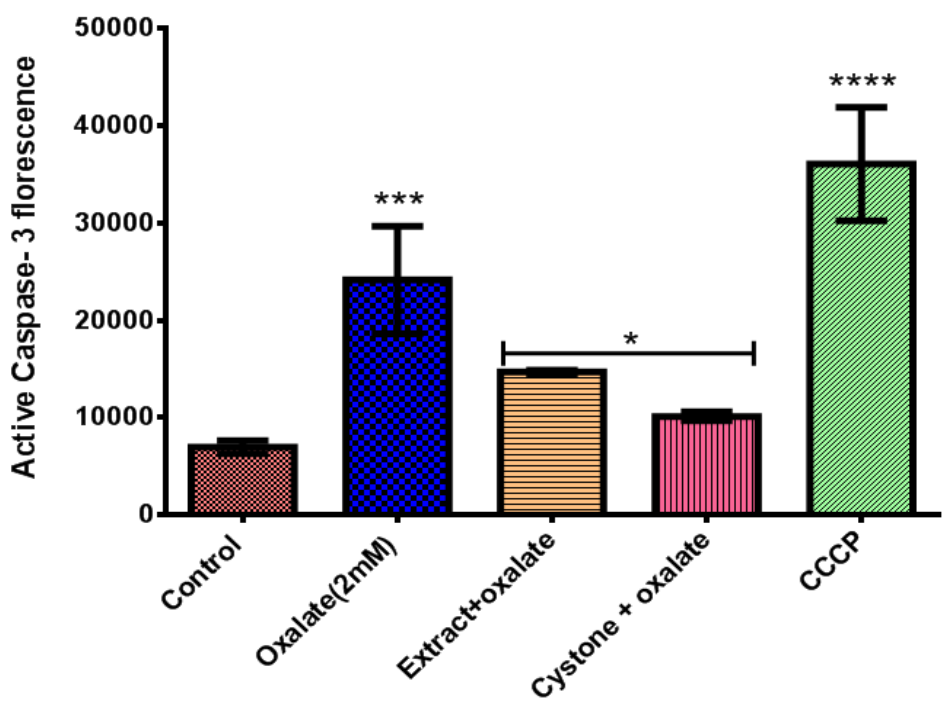

Figure 7. Activation of caspase-3 enzyme in oxalate injured cells due to apoptosis and decrease in fluorescence of oxalate injured cells cotreated with $D$. pedicellata extract $(100 \mu \mathrm{g} / \mathrm{mL})$. * $\mathrm{p}<0.01, * * * \mathrm{p}<0.001 * * * * \mathrm{p}<$ 0.0001 versus untreated control.

When exposed to HK2 cells, oxalate crystals cause a decrease in cell to cell and cell to matrix adhesive binding through alteration in the expression of cell adhesion molecules like OPN [48]. It further leads to a series of events within the cells organized by the modulation of various molecules involved in ROS generation, oxidative stress, adhesion of calcium oxalate crystals to the cell membrane, and apoptosis [45,46,48-50]. A glycoprotein, OPN is secreted by renal epithelial cells, which are involved in $\mathrm{CaOx}$ adhesion. Its expression is upregulated in the cortical region of the kidney following renal epithelial cell injury [51-53].

OPN is a bone matrix protein and an adhesion molecule that plays an imperative role in the adhesion of renal cells, as observed in the immunofluorescence assay [54]. As can be seen from Figure 8, the red fluorescence of the control cells is almost negligible, indicating that the OPN expression of this group was the lowest. OPN expression was the highest in the cells of the oxalate injured group. The reduction in OPN expression was seen in oxalate injured cells co-treated with $D$.pedicellata extract, thereby reducing calcium oxalate crystal adhesion and 
the threat of stone formation. A significant increase in apoptotic proteins and adhesion molecules in renal epithelial cells in retaliation to oxalate exposure could trigger the cascade of events, ultimately resulting in apoptosis.

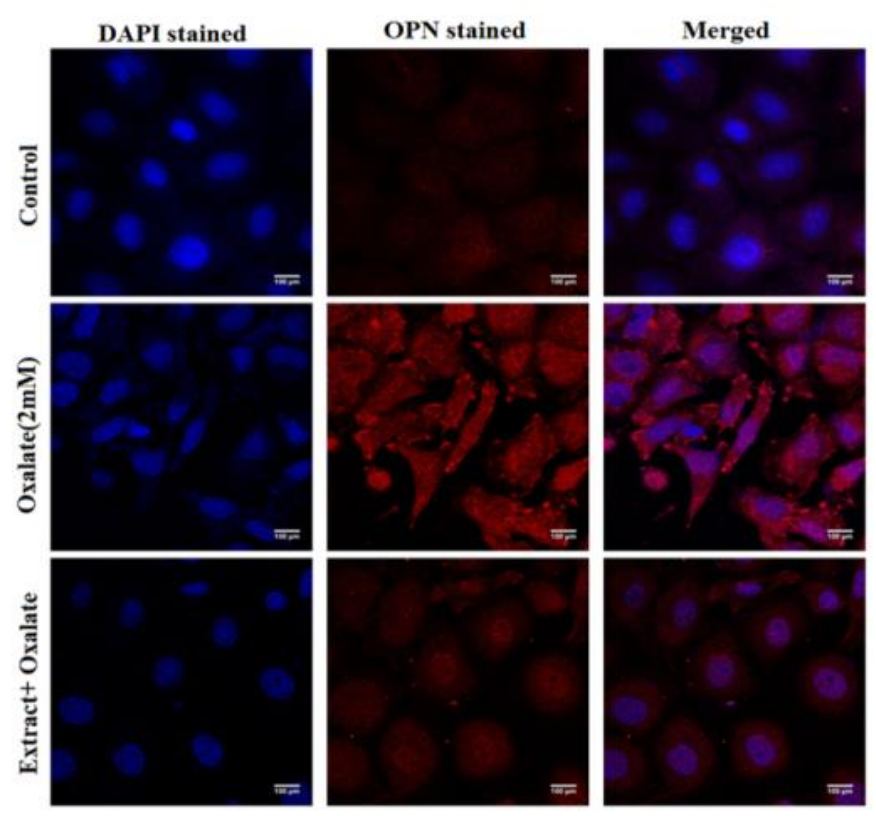

Figure 8. Adhesion Expression studies of OPN: Detection of OPN expression through Immunocytochemistry of HK2 cells using a confocal microscope. Fluorescence staining analysis of OPN expression in healthy cells stained with DAPI and OPN antibody is minimum, cells injured due to oxalate crystals show significant red fluorescence, and cells co-treated with $D$. pedicellata extract show reduction in red fluorescence.

\section{Conclusion}

This study highlights the ability of the ethanolic extract of $D$. pedicellata to reduce the extent of calcium oxalate-induced cytotoxicity through modulation of crystal structure. $D$. pedicellata reduced oxidative stress injury and apoptosis HK-2 cells by reducing the production of ROS. This provides new ideas for the prevention of the formation of kidney stones.

\section{Funding}

This research received no external funding.

\section{Acknowledgments}

This work was carried out at Amity University, Noida, India. The authors thank Mr. Manoj Kumar Gupta for the help in carrying out the flow cytometry analysis. Graphical abstract was prepared using Biorender application software.

\section{Conflicts of Interest}

The authors declare no conflict of interest.

\section{References}

1. Wong, Y.V.; Cook, P.; Somani, B.K. The Association of Metabolic Syndrome and Urolithiasis. International Journal of Endocrinology 2015, http://dx.doi.org/10.1155/2015/570674. 
2. Daudon, M.; Frochot, V.; Bazin, D.; Jungers, P. Drug-Induced Kidney Stones and Crystalline Nephropathy: Pathophysiology, Prevention and Treatment. Drugs 2018, 78, 163-201, https://doi.org/10.1007/s40265-0170853-7.

3. Prajapati, S.; Tomar, B.; Srivastava, A.; Narkhede, Y.B.; Gaikwad, A.N.; Lahiri, A.; Mulay, S.R. 6,7Dihydroxycoumarin ameliorates crystal-induced necroptosis during crystal nephropathies by inhibiting MLKL phosphorylation. Life Sciences 2021, 271, 119193, https://doi.org/10.1016/j.lfs.2021.119193.

4. Demoulin, N.; Aydin, S.; Gillion, V.; Morelle, J.; Jadoul, M.; Pathophysiology and Management of Hyperoxaluria and Oxalate Nephropathy: A Review. American Journal of Kidney Diseases 2021, https://doi.org/10.1053/j.ajkd.2021.07.018.

5. Espinosa-Ortiz, E.J.; Eisner, B.H.; Lange, D.; Gerlach, R. Current insights into the mechanisms and management of infection stones. Nature reviews. Urology 2019, 16, 35-53, http://doi:10.1038/s41585-0180120-z.6.

6. Khan, S. R. Reactive oxygen species, inflammation and calcium oxalate nephrolithiasis. Transl Androl Urol 2014, 3, 256-276, https://doi.org/10.3978/j.issn.2223-4683.2014.06.04.

7. Petrović, A.; Kizivat, T.; Bilić Ćurčić, I.; Smolić, R.; Smolić, M. In vitro Cell Culture Models of Hyperoxaluric States: Calcium Oxalate and Renal Epithelial Cell Interactions. Crystals 2021, 11, http://doi.org/10.3390/cryst11070735.

8. Lv, P.; Liu, H.; Ye, T.; Yang, X.; Duan, C.; Yao, X.; Li, B.; Tang, K.; Chen, Z.; Liu, J.; et al. XIST Inhibition Attenuates Calcium Oxalate Nephrocalcinosis-Induced Renal Inflammation and Oxidative Injury via the miR-223/NLRP3 Pathway. Oxidative medicine and cellular longevity 2021, 2021, 1676152, http://doi.org/10.1155/2021/1676152.

9. Peerapen, P.; Thongboonkerd, V. Differential bound proteins and adhesive capabilities of calcium oxalate monohydrate crystals with various sizes. Int $J$ Biol Macromol 2020, 15, 2210-2223, https://doi.org/10.1016/j.ijbiomac.2020.09.085.

10. Saha, S.; Goswami, G.; Pandrangi, A. Isolation and prevention of calcium oxalate induced apoptotic death and oxidative stress in MDCK cells by diosgenin. Chem Biol Interact 2014, 224, 51-57, https://doi.org/10.1016/j.cbi.2014.09.016.

11. Wang, Z.; Li, M.X.; Xu, C.Z.; Zhang, Y.; Deng, Q.; Sun, R.; Hu Q.Y.; Zhang, S.P.; Zhang, J.W.; Liang, H. Comprehensive study of altered proteomic landscape in proximal renal tubular epithelial cells in response to calcium oxalate monohydrate crystals. BMC Urol 2020, 20, 136, https://doi.org/10.1186/s12894-020-00709$\mathrm{z}$.

12. Martin-Sanchez, D.; Poveda, J.; Fontecha-Barriuso, M.; Ruiz-Andres, O.; Sanchez-Nino, M.D.; Ruiz-Ortega, M.; Ortiz, A.; Sanz, A.B. Targeting of regulated necrosis in kidney disease. Nefrología 2018, 38, 125-135, https://doi.org/10.1016/j.nefroe.2018.02.004.

13. Thamilselvan, S.; Khan, S. R.; Menon, M. Oxalate and calcium oxalate mediated free radical toxicity in renal epithelial cells: effect of antioxidants. Urol. Res 2003, 31, 3-9, https://doi.org/10.1007/s00240-002-0286-X.

14. Sun, X.Y.; Gan, Q.Z.; Ouyang, J.M. Calcium oxalate toxicity in renal epithelial cells: the mediation of crystal size on cell death mode. Cell Death Discovery 2015, 15055, https://doi.org/10.1038/cddiscovery.2015.55.

15. Mulay, S.R.; Shi, C.; Ma, X.; Anders, H.J. Novel Insights into Crystal-Induced Kidney Injury. Kidney diseases (Basel, Switzerland) 2018, 4, 49-57, http://doi.org/10.1159/000487671.

16. Zhao, Y.W.; Liu, L.; Li, C.Y.; Zhang, H.; Sun, X.Y. Preprotection of Tea Polysaccharides with Different Molecular Weights Can Reduce the Adhesion between Renal Epithelial Cells and Nano-Calcium Oxalate Crystals. Oxid Med Cell Longev 2020, 2020, https://doi.org/10.1155/2020/1817635.

17. Bashir, S.; Gilani, A. H. Antiurolithic effect of Bergenia ligulata rhizome: an explanation of the underlying mechanisms. J. Ethnopharmacol 2009, 122, 106-116, https://doi.org/10.1016/j.jep.2008.12.004.

18. Sofowora, A.; Ogunbodede, E.; Onayade, A. The Role and Place of Medicinal Plants in the Strategies for Disease Prevention. Afr J Tradit Complement Altern Med 2013, 10, 210-229, https://doi.org/10.4314/ajtcam.v10i5.2.

19. Nadkarni, A.K. Indian Materia Medica I-II Popular Prakashan, Bombay, vol 1,1976.

20. Kaur, G.; Lone, I.A.; Athar, M.; Alam, M.S. Protective effect of Didymocarpus pedicellata on ferric nitrilotriacetate (Fe-NTA) induced renal oxidative stress and hyperproliferative response. ChemicoBiological Interactions 2007, 165, 33-44, https://doi.org/10.1016/j.cbi.2006.10.012.

21. Sharma, B.M.; Panagariya, A.; Jain, K. Clinical trial of cystone in various renal disorders, Probe 2, 1983, $113-114$ 
22. Misgar, M. S. Controlled trial in 100 cases with nephrourethrolithiasis with cystone, an indigenous drug and other advanced methods. Curr. Med. Pract. 1982, 5, 26-29.

23. Rai, S.C. Clinical trials with cystone in urolithiasis. Curr. Med. Pract 1960,9, 484-487.

24. Garg, S.K, Singh, R.C. Role of cystone in burning micturation. Probe 2, 1985, 119-121.

25. Warsi, S.J. The constituents of Didymocarpus pedicellata. Part IV. Isolation of two new colouring matters and their relationship to pedicin. Indian chem. Soc. 1939, 16, 519-524.

26. Bose, C.P; Adityachaudhury, N. Didymocarpin, a new flavanone from Didymocarpus pedicellata. Phytochemistry 1978, 17, 587-588.

27. Gleberzon, J.S.; Liao,Y.; Mittler, S.; Goldberg, H.A.; Grohe, B. Incorporation of osteopontin peptide into kidney stone-related calcium oxalate monohydrate crystals: a quantitative study. Urolithiasis 2019, 47, 425440, https://doi.org/10.1007/s00240-018-01105-x.

28. Bhardwaj, R.; Bhardwaj, A.; Tandon, C.; Dhawan, D.K.; Bijarnia, R.K.; Kaur, T. Implication of hyperoxaluria on osteopontin and ER stress mediated apoptosis in renal tissue of rats. Experimental and Molecular Pathology 2017, 102, 384-390, https://doi.org/10.1016/j.yexmp.2017.04.002.

29. Liu, Q.; Liu, Y.; Guan, X.; Wu, J.; He, Z.; Kang, J.; Tao, Z.; Deng, Y. Effect of M2 Macrophages on Injury and Apoptosis of Renal Tubular Epithelial Cells Induced by Calcium Oxalate Crystals. Kidney Blood Press Res 2019, 44, 777-791, https://doi.org/10.1159/000501558.

30. de Araújo, L.; Costa-Pessoa, J.M.; de Ponte, M.C.; Oliveira-Souza, M. Sodium Oxalate-Induced Acute Kidney Injury Associated With Glomerular and Tubulointerstitial Damage in Rats. Front. Physiol 2020, 11, 1076, https://doi.org/10.3389/fphys.2020.01076.

31. Mehrotra, S.; Jamwal, R.; Shyam, R.; Meena, D.K.; Mishra, K.; Patra, R.; De, R.; Mukhopadhyay, A.; Srivastava, A.S.; Nandi, S.P. Anti-Helicobacter pylori and antioxidant properties of Emblica officinalis pulp extract: a potential source for therapeutic use against gastric ulcer. Journal Med. Plants Res 2011, 5, 25772583, https://doi.org/10.5897/JMPR.

32. Alelign, T.; Petros, B. Kidney Stone Disease: An Update on Current Concepts. Adv Urol 2018, 2018, https://doi.org/10.1155/2018/3068365.

33. Miyazawa, K.; Suzuki, K.; Ikeda, R.; Moriyama, M.T.; Ueda, Y.; Katsuda, S. Apoptosis and its related genes in renal epithelial cells of the stone-forming rat. Urol. Res 2005, 33, 31-38, https://doi.org/10.1007/s00240004-0434-6.

34. Obeng, E. Apoptosis (programmed cell death) and its signals - A review. Braz J Biol 2021, 81, 1133-1143, https://doi.org/10.1590/1519-6984.22843.

35. He, Z.; Liao, W.; Song, Q.; Li, B.; Liu, J.; Xiong, Y.; Song, C.; Yang, S. Role of ferroptosis induced by a high concentration of calcium oxalate in the formation and development of urolithiasis. Int $\mathrm{J}$ Mol Med 2021,47, 289-301, https://doi.org/10.3892/ijmm.2020.4770.

36. Ma, S.M.; Mao, Q.; Yi, L.; Zhao, M.Q.; Chen, J.D. Apoptosis, Autophagy, and Pyroptosis: Immune Escape Strategies for Persistent Infection and Pathogenesis of Classical Swine Fever Virus. Pathogens 2019, 8, 239, https://doi.org/10.3390/pathogens8040239.

37. Galluzzi, L.; Vitale, I.; Aaronson, S.; Abrams, J.M.; Adam, D.; Agostinis, P.; Alnemari, E.S et al. Molecular mechanisms of cell death: recommendations of the Nomenclature Committee on Cell Death. Cell Death Differentiation 2018, 25, 486-541, https://doi.org/10.1038/s41418-017-0012-4.

38. Liguori, I.; Russo, G.; Curcio, F.; Bulli, G.; Aran, L.; Della-Morte, D.; Gargiulo, G.; Testa, G.; Cacciatore, F.; Bonaducce, D.; Abete, P. Oxidative stress, aging, and diseases. Clin Interv Aging 2018, 13, 757-772, https://doi.org/10.2147/CIA.S158513.

39. Tarozzi, A. Oxidative Stress in Neurodegenerative Diseases: From Preclinical Studies to Clinical Applications. J. Clin. Med 2020, 9, 1223, https://doi.org/10.3390/jcm9041223.

40. De Bellis, R.; Piacentini, M.P.; Meli, M.A.; Mattioli, M.; Menotta, M.; Mari, M.; Valentini, L.; Palomba, L.; Desideri, D.; Chiarantini, L. In vitro effects on calcium oxalate crystallization kinetics and crystal morphology of an aqueous extract from Ceterach officinarum: Analysis of a potential antilithiatic mechanism. PLoS ONE 2019, 14, e0218734, https://doi.org/10.1371/journal.pone.0218734.

41. Gan, Q.; Sun, X.; Bhadja, P.; Yao, X.; Ouyang, J. Reinjury risk of nano-calcium oxalate monohydrate and calcium oxalate dihydrate crystals on injured renal epithelial cells: aggravation of crystal adhesion and aggregation. Int J Nanomedicine 2016, 11, 2839-2854, https://doi.org/10.2147/IJN.S104505.

42. Gomes, D.L.; Melo, K.R.; Queiroz, M.F.; Batista, L.A.; Santos, P.C.; Costa, M.S.; Almeida-Lima, J.; Camara, R.B.; Costa, L.S.; Rocha, H.A. In vitro Studies Reveal Antiurolithic Effect of Antioxidant Sulfated 
Polysaccharides from the Green Seaweed Caulerpa cupressoides var flabellata. Marine Drugs 2019, 17, http://doi.org/10.3390/md17060326.

43. Kletzmayr, A.; Mulay, S.R.; Motrapu, M.; Luo, Z.; Anders, H.J.; Ivarsson, M.E.; Leroux, J.C. Inhibitors of Calcium Oxalate Crystallization for the Treatment of Oxalate Nephropathies. Adv. Sci 2020, 7, 1903337 , https://doi.org/10.1002/advs.201903337.

44. Redza-Dutordoir, M.; Averill-Bates, D.A. Activation of apoptosis signalling pathways by reactive oxygen species. Biochimica et Biophysica Acta (BBA) - Molecular Cell Research 2016, 1863, 2977-2992, https://doi.org/10.1016/j.bbamcr.2016.09.012.

45. Lu, X.; Gao, B.; Wang, Y.; Liu, Z.; Yasui, T.; Liu, P.; Liu, J.; Emmanuel, N.; Zhu, Q.; Xiao, C. Renal tubular epithelial cell injury, apoptosis and inflammation are involved in melamine-related kidney stone formation. Urol. Res 2012, 40, 717-723, https://doi.org/10.1007/s00240-012-0507-x.

46. Pradelli, L.A.; Beneteau, M.; Ricci, J.E. Mitochondrial control of caspase-dependent and independent cell death. Cell. Mol. Life Sci 2010, 67, 1589-1597, https://doi.org/10.1007/s00018-010-0285-y.

47. Wen, S.; Wang, Z.H.; Zhang, C.X.; Yang,Y.; Fan, Q.L. Caspase-3 Promotes Diabetic Kidney Disease Through Gasdermin E-Mediated Progression to Secondary Necrosis During Apoptosis. Diabetes Metab Syndr Obes 2020, 13, 313-323, https://doi.org/10.2147/DMSO.S242136.

48. Li, X.; Chen, S.; Feng, D.; Fu, Y.; Wu, H.; Lu, J.; Bao, J. Calcium-sensing receptor promotes calcium oxalate crystal adhesion and renal injury in Wistar rats by promoting ROS production and subsequent regulation of PS ectropion, OPN, KIM-1, and ERK expression. Renal failure 2021, 43, 465-476, https://doi.org/10.1080/0886022X.2021.1881554.

49. Chaiyarit, S.; Thongboonkerd, V. Mitochondrial dysfunction and kidney stone disease. Front. Physiol 2020, 11, 566506, https://doi.org/10.3389/fphys.2020.566506.

50. Sun, Y.; Dai, S.; Tao, J.; Li, Y.; He, Z. Taurine suppresses ROS-dependent autophagy via activating Akt/mTOR signaling pathway in calcium oxalate crystals-induced renal tubular epithelial cell injury. Aging, 2020, 12, 17353-17366, https://doi.org/10.18632/aging.103730.

51. Xi, Q.; Ouyang, J.; Pu, J.; Hou, J.; Wang, S. High concentration of calcium stimulates calcium oxalate crystal attachment to rat tubular epithelial NRK cells through osteopontin. Urology 2015, 86, https://doi.org/10.1016/j.urology.2015.07.018.

52. Christensen, B.; Petersen, T.E.; Sorensen, E.S. Post-translational modification and proteolytic processing of urinary osteopontin. Biochem. Journal 2008, 411, 53-61, https://doi.org/10.1042/BJ20071021.

53. Kaleta, B. The role of osteopontin in kidney diseases. Inflammation Research 2019, 68, 93-102, https://doi.org/10.1007/s00011-018-1200-5.

54. Hirose, M.; Tozawa, K.; Okada, A.; Hamamoto, S.; Higashibata, Y.; Gao, B.; Hayashi, Y.; Shimizu, H.; Kubota, Y.; Yasui, T.; et al. Role of osteopontin in early phase of renal crystal formation: immunohistochemical and microstructural comparisons with osteopontin knock-out mice. Urological research 2012, 40, 121-129, https://doi.org/10.1007/s00240-011-0400-z. 